\title{
Telmatocola sphagniphila gen. nov., sp. nov., a novel dendriform planctomycete from northern wetlands
}

\author{
Irina S. Kulichevskaya ${ }^{1}$, Yulia M. Serkebaeva ${ }^{1,2}$, Yongkyu Kim ${ }^{2}$, W. Irene C. Rijpstra ${ }^{3}$, \\ Jaap S. Sinninghe Damsté ${ }^{3}$, Werner Liesack ${ }^{2}$ and Svetlana N. Dedysh ${ }^{1}$ * \\ S.N. Winogradsky Institute of Microbiology, Russian Academy of Sciences, Moscow, Russia \\ ${ }^{2}$ Max-Planck-Institut für Terrestrische Mikrobiologie, Marburg, Germany \\ ${ }^{3}$ Department of Marine Organic Biogeochemistry, NIOZ Royal Netherlands Institute for Sea Research, AB Den Burg, Netherlands
}

\section{Edited by:}

Naomi L. Ward, University of

Wyoming, USA

Reviewed by:

Kirk Matthew Schnorr, Novozymes

A/S, Denmark

Evelyne Forano, Institut National de la

Recherche Agronomique, France

\section{*Correspondence:}

Svetlana N. Dedysh, Winogradsky Institute of Microbiology, Russian Academy of Sciences, Prospect

60-Letya Octyabrya 7/2, Moscow

117312, Russia.

e-mail:dedysh@mail.ru
Members of the phylum Planctomycetes are common inhabitants of northern wetlands. We used barcoded pyrosequencing to survey bacterial diversity in an acidic (pH 4.0) Sphagnum peat sampled from the peat bog Obukhovskoye, European North Russia. A total of 21189 bacterial 16S rRNA gene sequences were obtained, of which 1081 reads (5.1\%) belonged to the Planctomycetes. Two-thirds of these sequences affiliated with planctomycete groups for which characterized representatives have not yet been available. Here, we describe two organisms from one of these previously uncultivated planctomycete groups. One isolate, strain OB3, was obtained from the peat sample used in our molecular study, while another strain, SP2 ${ }^{\top}\left(=\mathrm{DSM} 23888^{\top}=\mathrm{VKM} B-2710^{\top}\right)$, was isolated from the peat bog Staroselsky moss. Both isolates are represented by aerobic, budding, pink-pigmented, non-motile, spherical cells that are arranged in unusual, dendriform-like structures during growth on solid media. These bacteria are moderately acidophilic and mesophilic, capable of growth at pH 4.0-7.0 (optimum pH 5.0-5.5) and at 6-30 ${ }^{\circ} \mathrm{C}$ (optimum $20-26^{\circ} \mathrm{C}$ ). The preferred growth substrates are various heteropolysaccharides and sugars, the latter being utilized only if provided in low concentrations $(\leq 0.025 \%)$. In contrast to other described planctomycetes, strains $\mathrm{SP}^{\top}$ and $\mathrm{OB} 3$ possess weak cellulolytic

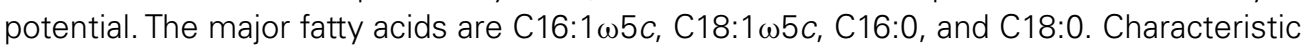
lipids are the $n$-C31 polyunsaturated alkene (9-10 double bonds) and C30:1/C32:1 ( $\omega-1)$ hydroxy fatty acids. The G $+C$ content of the DNA is $58.5-59.0$ mol\%. Strains SP2 ${ }^{\top}$ and OB3 share identical 16S rRNA gene sequences, which exhibit only 86 and $87 \%$ similarity to those of Gemmata obscuriglobus and Zavarzinella formosa. Based on the characteristics reported here, we propose to classify these novel planctomycetes as representatives of a novel genus and species, Telmatocola sphagniphila gen. nov., sp. nov.

Keywords: the phylum Planctomycetes, Telmatocola sphagniphila gen. nov., sp. nov., cellulolytic planctomycete, dendriform cell morphology, acidic northern wetlands

\section{INTRODUCTION}

The planctomycetes is a ubiquitously distributed and a largely unexplored bacterial phylum, which contains only a limited number of taxonomically characterized representatives (Fuerst, 1995; Ward et al., 2006; Fuerst and Sagulenko, 2011). At present, the list of validly described planctomycetes includes the genera Planctomyces (Gimesi, 1924), Pirellula (Schlesner and Hirsch, 1987), Blastopirellula, Rhodopirellula (Schlesner et al., 2004), Isosphaera (Giovannoni et al., 1987), Gemmata (Franzmann and Skerman, 1984), Schlesneria (Kulichevskaya et al., 2007b), Singulisphaera (Kulichevskaya et al., 2008), Zavarzinella (Kulichevskaya et al., 2009), and Aquisphaera (Bondoso et al., 2011). These 10 genera accommodate 16 species, which differ in cell morphology, ecophysiological adaptations, substrate preferences, and other phenotypic and genotypic characteristics. However, all members of these species display a number of common features including a budding mode of cell division, peptidoglycan-less cell walls, and a unique cell organization (Staley et al., 1992; Fuerst, 1995, 2005; Ward et al., 2006). All taxonomically characterized planctomycetes are chemoheterotrophs; many of them are capable of degrading various heteropolysaccharides but not cellulose or chitin.

Highly distinctive cell morphology is typical for many planctomycetes. Rosettes of spherical cells joined together by non-cellular stalks represent one of the most fascinating planctomycete morphotypes, which is characteristic of Planctomyces bekefii. This species has never been isolated in pure culture and was described based solely on its specific morphology (Gimesi, 1924). The same is true for two other species of the genus Planctomyces, P. guttaeformis, and P. stranskae (Starr and Schmidt, 1984). Traditionally, these rosette-forming stalked morphotypes that are commonly observed in various aquatic environments have been classified as belonging to the genus Planctomyces. Recently, however, we reported that the presence of a stalk and a similar rosette-like cell arrangement is typical for the novel Gemmata-like planctomycete, Zavarzinella formosa (Kulichevskaya et al., 2009). The latter bacterium was isolated from acidic Sphagnum peat, which is densely colonized by members of the Planctomycetes (Dedysh et al., 2006; Kulichevskaya et al., 2006; Ivanova and Dedysh, 2012). 
Our further cultivation efforts resulted in the isolation of two other peat-inhabiting, morphologically unique, Gemmatalike planctomycetes, strains $\mathrm{SP} 2^{\mathrm{T}}$ and $\mathrm{OB} 3$, from two North European Sphagnum peat bogs Staroselsky moss and Obukhovskoye. When grown on solid media, spherical cells of these bacteria were arranged in unusual, dendriform-like structures. The peat sample used for isolating strain OB3 was also used for pyrosequencingbased Bacteria diversity analysis. This analysis indicated that microorganisms related to strains $\mathrm{SP} 2^{\mathrm{T}}$ and $\mathrm{OB} 3$ made a significant proportion of peat-inhabiting planctomycetes. In order to characterize phenotypic properties of the newly isolated planctomycetes and to understand their functional role in Sphagnum peat, this work was initiated.

\section{MATERIALS AND METHODS SAMPLING SITES}

The acidic ( $\mathrm{pH}$ 3.8) peat soil used for isolation of strain $\mathrm{SP} 2^{\mathrm{T}}$ was sampled in August 2008 from the upper oxic layer $(5-10 \mathrm{~cm})$ of the Sphagnum-dominated ombrotrophic peat bog Staroselsky moss, Tver region, European North Russia $\left(56^{\circ} 34^{\prime} \mathrm{N}, 32^{\circ} 46^{\prime} \mathrm{E}\right)$. The second peat sample ( $\mathrm{pH} 4.0$ ), which was used for isolation of strain OB3 and for the molecular diversity analysis, was collected in June 2010 at a depth of $0-10 \mathrm{~cm}$ of the Sphagnum-dominated, ombrotrophic peat bog Obukhovskoye, Yaroslavl region, European North Russia $\left(58^{\circ} 14^{\prime} \mathrm{N}, 38^{\circ} 120^{\prime} \mathrm{E}\right)$. This wetland was described previously (Pankratov et al., 2011). During each sampling event, five subsamples collected from the particular wetland site were combined to form one composite sample. The samples were transported to the laboratory in boxes containing ice packs, homogenized by cutting the peat material into small fragments (about $0.5 \mathrm{~cm}$ ) with sterile scissors, and used to inoculate enrichment cultures or frozen at $-20^{\circ} \mathrm{C}$ for DNA extraction within 1 day after sampling.

\section{DNA EXTRACTION, PCR AMPLIFICATION, AND PYROSEQUENCING}

Three subsamples, each of $0.5 \mathrm{~g}$ wet weight, were taken from the peat sample collected from the ombrotrophic bog Obukhovskoye and processed separately. The extraction was performed using a FastDNA SPIN kit for Soil (Bio101, Carlsbad, USA) according to manufacturer's instruction. Polymerase chain reaction was carried out using the Bacteria-specific primers 907F (5'-AAA CTY AAA KGA ATT GAC GG-3') and 1392R ( $5^{\prime}$-ACG GGC GGT GTG TRC-3'; Lane, 1991). The 907F primer included a 454-A pyrosequencing adaptor and a 6-bp barcode sequence, while the $1392 \mathrm{R}$ primer incorporated a 454-B pyrosequencing adaptor. PCR amplifications were performed in a DNA thermal cycler (model 9700; PE Applied Biosystems) under the following conditions: initial denaturation $\left(3 \mathrm{~min}\right.$ at $\left.95^{\circ} \mathrm{C}\right) ; 30$ cycles consisting of denaturation $\left(30 \mathrm{~s}\right.$ at $\left.95^{\circ} \mathrm{C}\right)$, primer annealing $\left(45 \mathrm{~s}\right.$ at $\left.55^{\circ} \mathrm{C}\right)$, and elongation $\left(90 \mathrm{~s}\right.$ at $72^{\circ} \mathrm{C}$ ), with a final elongation step for $8 \mathrm{~min}$ at $72^{\circ} \mathrm{C}$. All samples were amplified in triplicate, pooled in equal amounts, and purified using Wizard ${ }^{\circledR}$ SV Gel and PCR Clean-Up System (Promega, Madison, USA). Quantification of the PCR products was performed using Quant-iT dsDNA BR assay kit and Qubit fluorometer (Invitrogen GmbH, Karlsruhe, Germany). The purified products were subjected to 454-pyrosequencing at the Max Planck Genome Centre Cologne, Germany.

\section{DATA ANALYSIS}

We used Mothur (Schloss et al., 2009) to trim the primer sequences and to remove low quality and short $(<400-\mathrm{bp})$ sequences. The sequences were further refined by removing chimeras with the UCHIME (Edgar et al., 2011) algorithm implemented in Mothur. Taxonomy-based analysis of the resulting sequence pool was made by using Mothur and SILVA-based template database as a reference (Pruesse et al., 2007), at a confidence threshold of $80 \%$. The $16 \mathrm{~S}$ rRNA gene sequences of representatives of the planctomycetes were retrieved from the total sequence pool and clustered by using Mothur.

\section{ISOLATION AND MAINTENANCE OF STRAINS SP2 ${ }^{\top}$ AND OB3}

Two grams of wet peat were suspended in $10 \mathrm{ml}$ of sterile water and treated in a laboratory stomacher at $240 \mathrm{rpm}$ for $5 \mathrm{~min}$. The resulting peat suspension was used to inoculate $500-\mathrm{ml}$ serum bottles containing $90 \mathrm{ml}$ of sterile dilute mineral medium M1 of the following composition (gram per liter of distilled water): $\mathrm{KH}_{2} \mathrm{PO}_{4}$, $0.1 ;\left(\mathrm{NH}_{4}\right)_{2} \mathrm{SO}_{4}, 0.1 ; \mathrm{MgSO}_{4} \times 7 \mathrm{H}_{2} \mathrm{O}, 0.1 ; \mathrm{CaCl}_{2} \times 2 \mathrm{H}_{2} \mathrm{O}, 0.02$; $1 \mathrm{ml}$ of trace element solution " 44 " and $1 \mathrm{ml}$ Staley's vitamin solution (Staley et al., 1992); pH 4.8-5.5. The bottles were tightly closed and incubated in the dark at room temperature. After 4 weeks of incubation, 20- $\mu$ l aliquots of the resulting enrichment cultures were spread plated onto medium M1 containing $0.2 \mathrm{gl}^{-1}$ of Naampicillin and solidified with $10 \mathrm{~g}$ Phytagel (Sigma - Aldrich) The plates were then incubated at $22^{\circ} \mathrm{C}$ for 4 weeks in gastight jars containing $5 \% \mathrm{CO}_{2}(\mathrm{v} / \mathrm{v})$ in air, generated by $\mathrm{GENbox} \mathrm{CO}_{2}$ system envelopes (Biome'rieux). Colonies and microbial cell masses that developed on plates were screened microscopically for the presence of cells with planctomycete-like morphology. The selected cell material was re-streaked onto the same medium supplemented with $0.01 \%$ yeast extract and $0.025 \%$ glucose (medium M1N). This procedure was repeated until the target microorganism was obtained in a pure culture.

Isolates were maintained on medium $\mathrm{M} 1 \mathrm{~N}$ and were subcultured at 2 month intervals. Z. formosa $\mathrm{A}^{\mathrm{T}}{ }^{\mathrm{T}}$ (Kulichevskaya et al., 2009) and Gemmata obscuriglobus DSM $5831^{\mathrm{T}}$ (Franzmann and Skerman, 1984) were used as the reference strains in our study. $Z$. formosa $\mathrm{A} 10^{\mathrm{T}}$ was cultivated on agar medium M31 (Kulichevskaya et al., 2009), while G. obscuriglobus DSM $5831^{\mathrm{T}}$ was maintained on medium 629 recommended by the Deutsche Sammlung von Mikroorganismen und Zellkulturen (DSMZ, Braunschweig, Germany) for cultivation of this bacterium.

\section{MORPHOLOGICAL OBSERVATIONS AND PHYSIOLOGICAL TESTS}

Morphological observations and cell size measurements were made with a Zeiss Axioplan 2 microscope and Axiovision 4.2 software (Zeiss, Germany). Physiological tests were performed in liquid medium M1N. Growth of strains SP2 ${ }^{\mathrm{T}}$ and $\mathrm{OB} 3$ was monitored by nephelometry at $600 \mathrm{~nm}$ in an Eppendorf BioPhotometer for 14-21 days under a variety of conditions, including temperatures of $4-37^{\circ} \mathrm{C}, \mathrm{pH} 3.8-8.0$, and $\mathrm{NaCl}$ concentrations of $0-3.0 \%(\mathrm{w} / \mathrm{v})$. Variations in the $\mathrm{pH}$ were achieved by mixing $0.1 \mathrm{M}$ solutions of $\mathrm{H}_{2} \mathrm{SO}_{4}$ and $\mathrm{KOH}$. Carbon source utilization was determined using mineral medium M1 supplemented with $0.005 \%$ yeast extract and respective carbon sources $(0.025 \%, \mathrm{w} / \mathrm{v})$. Cultivation was done in 120-ml flasks containing $10 \mathrm{ml}$ medium. 
Cultures were incubated at $22^{\circ} \mathrm{C}$ for $2-3$ weeks on a shaker. The capability to degrade different biopolymers was examined by measuring the rate of $\mathrm{CO}_{2}$ production in tightly closed 160 -ml serum bottles for 1.5 months at $22^{\circ} \mathrm{C}$. The serum bottles contained $10 \mathrm{ml}$ of liquid medium M1 with $0.005 \%$ yeast extract as a growth factor and $0.05 \%(\mathrm{w} / \mathrm{v})$ of the corresponding polymer substrate. Control incubations were run in parallel under the same conditions but without a polymer substrate. Cellulolytic capabilities of strains $\mathrm{SP} 2^{\mathrm{T}}$ and $\mathrm{OB} 3$ were determined using sodium carboxymethyl cellulose (Fluka), microcrystalline cellulose (Aldrich), and fibrous cellulose $(0.05 \%, \mathrm{w} / \mathrm{v})$ as carbon sources. Fibrous cellulose was prepared from Whatman filter paper as described by Pankratov et al. (2011). Cellulose degradation was monitored by measuring $\mathrm{CO}_{2}$ production rates during incubation. $\mathrm{CO}_{2}$ concentration was measured with a non-dispersive infra-red gas-analyzer "Infralit" (Germany). The reducing sugar product was assayed by the dinitrosalicylic (DNS) method (Miller, 1959), using glucose as the sugar standard. All experiments were performed in triplicate. The purity of strains $\mathrm{SP} 2^{\mathrm{T}}$ and $\mathrm{OB} 3$ in the course of our experiments on cellulose degradation was controlled by means of whole-cell hybridization with Cy3-labeled 16S rRNAtargeted planctomycetes-specific oligonucleotide probes PLA46 and PLA886 (Neef et al., 1998).

Oxidative and fermentative utilization of carbohydrates was determined as described for the Hugh-Leifson test (Gerhardt, 1981). Nitrogen sources were tested using liquid medium M1N in which $(\mathrm{NH} 4)_{2} \mathrm{SO}_{4}$ was replaced with one of the following compounds at a concentration of $0.01 \%(\mathrm{w} / \mathrm{v}): \mathrm{KNO}_{3}, \mathrm{KNO}_{2}$, urea, or one of the amino acids listed in Table 1. Analyses of enzymatic profiles, gelatin, and urease hydrolysis, indole production and Hugh-Leifson test were made with API ZYM and API 20NE kits (Biome'rieux). Catalase and oxidase tests were carried out by standard methods (Gerhardt, 1981). Cultures were tested for growth under anaerobic conditions in anaerobic jars by using AnaeroGen anaerobic system envelopes (Oxoid). Susceptibility to antibiotics was determined on solid medium M1N using disks (Oxoid) containing the following antibiotics: ampicillin $(10 \mu \mathrm{g})$, gentamycin $(10 \mu \mathrm{g})$, kanamycin $(30 \mu \mathrm{g})$, neomycin $(10 \mu \mathrm{g})$, novobiocin $(30 \mu \mathrm{g})$, streptomycin $(10 \mu \mathrm{g})$, chloramphenicol $(30 \mu \mathrm{g})$, and lincomycin (10 $\mu \mathrm{g}$; Oxoid).

\section{LIPID ANALYSES}

For lipid analyses, cells of strains $\mathrm{SP} 2^{\mathrm{T}}$ and $\mathrm{OB} 3$ were grown on liquid medium $\mathrm{M} 1 \mathrm{~N}$ and harvested in the late exponential growth phase. Lipids were analyzed using the procedures described by Goossens et al. (1989). Briefly, cells were extracted with dichloromethane/methanol $(2 ; 1, \mathrm{v} / \mathrm{v})$ and the total extract was hydrolyzed by reflux in $1 \mathrm{~N}$ methanolic $\mathrm{KOH}$ for $1 \mathrm{~h}$. The residue of the extraction was also subjected to base hydrolysis. Fatty acids were methylated with diazomethane in diethyl ether and alcohols were silylated with BSTFA [N,OBis(trimethylsilyl)trifluoroacetamide] prior to analysis by gas chromatography and gas chromatography-mass spectrometry. To compare the results with the lipid compositions of $Z$. formosa $\mathrm{A} 10^{\mathrm{T}}$ and $G$. obscuriglobus DSM $5831^{\mathrm{T}}$, we used previously obtained extracts (Kulichevskaya et al.,2009) and performed direct hydrolysis on these extracts.

\section{GENOTYPIC ANALYSES}

Genomic DNA from strains $\mathrm{SP} 2^{\mathrm{T}}$ and $\mathrm{OB} 3$ was extracted as described by Marmur (1961). The G $+\mathrm{C}$ content of DNA was determined by means of thermal denaturation using a Unicam SP1800 spectrophotometer (UK) at a heating rate of $0.5^{\circ} \mathrm{C} \mathrm{min}{ }^{-1}$ and calculated according to Owen et al. (1969). DNA of Escherichia coli $\mathrm{K}-12$ ( $\mathrm{G}+\mathrm{C}$ value $51.7 \mathrm{~mol} \%$ ) was used as the standard. PCRmediated amplification of the 16S rRNA gene from positions 28 to 1491 (numbering according to the International Union of Biochemistry nomenclature for E. coli $16 \mathrm{~S}$ rRNA) was performed using primers $9 \mathrm{f}$ and 1492r and reaction conditions described by Weisburg et al. (1991). The 16S rRNA gene amplicons were purified using QIAquick spin columns (Qiagen) and sequenced on an ABI Prism 377 DNA sequencer using BigDye terminator chemistry, as specified by the manufacturer (PE Applied Biosystems). Phylogenetic analysis was carried out using the ARB program package (Ludwig et al., 2004).

\section{NUCLEOTIDE SEQUENCE ACCESSION NUMBERS}

The 16S rRNA gene sequence of Telmatocola sphagniphila SP2 ${ }^{\mathrm{T}}$ has been deposited in the EMBL, GenBank, and DDBJ nucleotide sequence databases under accession number JN880417.

\section{RESULTS AND DISCUSSION PYROSEQUENCING-BASED ASSESSMENT OF PLANCTOMYCETE DIVERSITY IN ACIDIC PEAT}

A total of 21189 partial (average length $\sim 490$ bp) bacterial $16 \mathrm{~S}$ rRNA gene sequences were obtained from the Sphagnum peat sample examined in our study. The major groups of sequences affiliated with the Acidobacteria (32.5\%), Proteobacteria (24.2\%), Actinobacteria (8.3\%), and Verrucomicrobia (7.5\%; Serkebaeva et al., unpublished data). This pattern of bacterial diversity is typical for Sphagnum-dominated wetlands (reviewed in Dedysh, 2011).

The relative abundance of the Planctomycetes in the bacterial community according to the pyrosequencing data was 5.1\% (1081 reads). The diversity of the planctomycete-related $16 \mathrm{~S}$ rRNA gene sequences in the amplicon library is illustrated in Figure 1A by rarefaction curves showing the expected number of operational taxonomic units encountered with increasing sequencing depth. Rarefaction curves showed a progressive trend to cover diversity but did not reach the asymptote, indicating that we failed to survey the full extent of planctomycete diversity in the particular peat sample.

Taxonomy-based analysis revealed that only $29 \%$ of all the planctomycete-related $16 \mathrm{~S}$ rRNA gene sequences affiliate with phylogenetic lineages defined by taxonomically described organisms, including members of the genera Isosphaera, Pirellula, Planctomyces, Schlesneria, and Singulisphaera (Figure 1B). The most frequently detected organisms were Isosphaera-like bacteria $(16.7 \%$ of all planctomycete-related sequences), which is line with the recently reported data on the planctomycetes diversity in oxic peat layers (Ivanova and Dedysh, 2012). The majority (71\%) of all planctomycete-related 16S rRNA gene sequences retrieved from acidic peat could not be assigned to taxonomically characterized organisms. One of the major sequence groups within this unclassified diversity, however, affiliated with strain $\mathrm{SP}_{2}{ }^{\mathrm{T}}$, one of the 
Table 1 | Phenotypic characteristics of strains $\mathrm{SP2}^{\top}$ and $\mathrm{OB} 3$ in comparison to those of Zavarzinella formosa $\mathrm{A10}^{\top}$ and Gemmata obscuriglobus DSM 5831'.

\begin{tabular}{|c|c|c|c|c|}
\hline Characteristic & Strain SP2 ${ }^{\top}$ & Strain OB3 & Z. formosa & G. obscuriglobus \\
\hline Cell size $(\mu \mathrm{m})$ & $1.2-2.0$ & $1.4-2.2$ & $2.5-3.2 \times 2.0-2.5$ & $1.4-3.0 \times 1.4-3.0$ \\
\hline Flagellation & - & - & Monotrichous & Polytrichous \\
\hline Rosette formation & + & + & + & - \\
\hline Stalk formation & + & + & + & - \\
\hline Salinity tolerance & $<0.1 \%$ & $<0.1 \%$ & $<0.6 \%$ & $<0.6 \%$ \\
\hline Glucose concentration & $\leq 0.025 \%$ & $\leq 0.025 \%$ & $\leq 0.05 \%$ & $\leq 0.1 \%$ \\
\hline $\mathrm{pH}$ growth range & $4.0-7.0$ & $4.2-7.0$ & $3.8-7.2$ & $7.8-8.8$ \\
\hline pH optimum & $5.0-5.5$ & $5.0-5.8$ & $5.5-6.0$ & ND \\
\hline Temperature range, ${ }^{\circ} \mathrm{C}$ & $6-30$ & $6-30$ & $10-30$ & $16-35$ \\
\hline Mannose & + & + & - & + \\
\hline Sorbose & - & - & + & - \\
\hline Raffinose & + & - & + & - \\
\hline $\mathrm{N}$-acetylglucosamine & $+(<0.01 \%)$ & $+(<0.01 \%)$ & + & + \\
\hline Pyruvate & - & - & + & - \\
\hline Chondroitin sulfate & - & - & + & + \\
\hline Pectin & - & - & + & + \\
\hline Carboxymethyl cellulose & + & + & - & - \\
\hline Cellulose & W & W & - & - \\
\hline \multicolumn{5}{|l|}{ ENZYMATIC ACTIVITIES } \\
\hline$\alpha$-Galactosidase & - & - & - & + \\
\hline
\end{tabular}

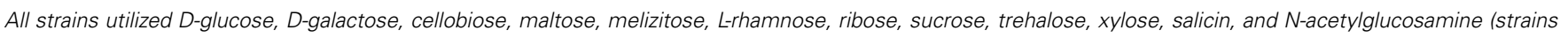
$S P 2^{T}$ and $\left.O B 3<0.01 \%\right)$. All strains were capable of hydrolyzing laminarin, aesculin, starch, gelatin, lichenan, and xylan. Substrates tested but not utilized: fructose, fucose, glycerol, gluconate, methanol, ethanol, galacturonate, acetate, benzoate, caproate, citrate, formate, formaldehyde, fumarate, glutarate, lactate, malate, succinate, propionate, mannitol, tartrate, alanine, arginine, asparagine, aspartate, cysteine, cystine, glutamine, glycine, histidine, isoleucine, leucine, lysine, methionine, norleucine, ornithine, phenylalanine, proline, serine, threonine, tryptophan, tyrosine, valine. None of the strains was capable of hydrolyzing casein, chitosan, and chitin. All strains utilized nitrate, ammonia, Bacto Yeast Extract, glutamine, asparagine as nitrogen sources. All strains were positive for catalase, did not reduce nitrate to nitrite, did not produce indole from tryptophane, and did not ferment glucose. ND, not determined; w, weak growth or weak activity.

as-yet-uncharacterized isolates in our collection of peat-inhabiting planctomycetes. This isolate was obtained in 2008 from the Sphagnum peat bog Staroselsky moss, European North Russia, and was phylogenetically identified as a planctomycete distantly related to G. obscuriglobus and Z. formosa (86 and $87 \%$ sequence similarity, respectively; Figure 2). Strain $\mathrm{SP} 2^{\mathrm{T}}$-related $16 \mathrm{~S}$ rRNA gene sequences comprised $10 \%$ of all the planctomycete-related 454 reads obtained from the peat bog Obukhovskoye, suggesting that strain $\mathrm{SP} 2^{\mathrm{T}}$ is a typical representative of the planctomycetes community in peat bogs. This finding prompted us address this bacterial group in more detail.

\section{ISOLATION AND IDENTIFICATION}

The enrichment approach that implies the use of dilute media and gives a selective advantage to planctomycetes was designed earlier (Hirsch and Müller, 1985; Schlesner, 1994). In our recent experiments on Sphagnum moss decomposition, we noticed that moss (or moss-derived peat) can be used as the growth substrate for planctomycetes, which usually develop at the final stage of decomposition process, after several weeks of incubation (Kulichevskaya et al., 2007a). Therefore, we used long-term incubation of a dilute mineral medium inoculated with peat suspension as a specific factor to enrich for peat-inhabiting planctomycetes. Using this 
approach, we isolated strain $\mathrm{SP} 2^{\mathrm{T}}$ from the Sphagnum peat bog Staroselsky moss in 2008. Growth requirements of this isolate, however, were somewhat different from those in other characterized peat-inhabiting planctomycetes, and it took us nearly 2 years to optimize its laboratory growth conditions. By that time, we
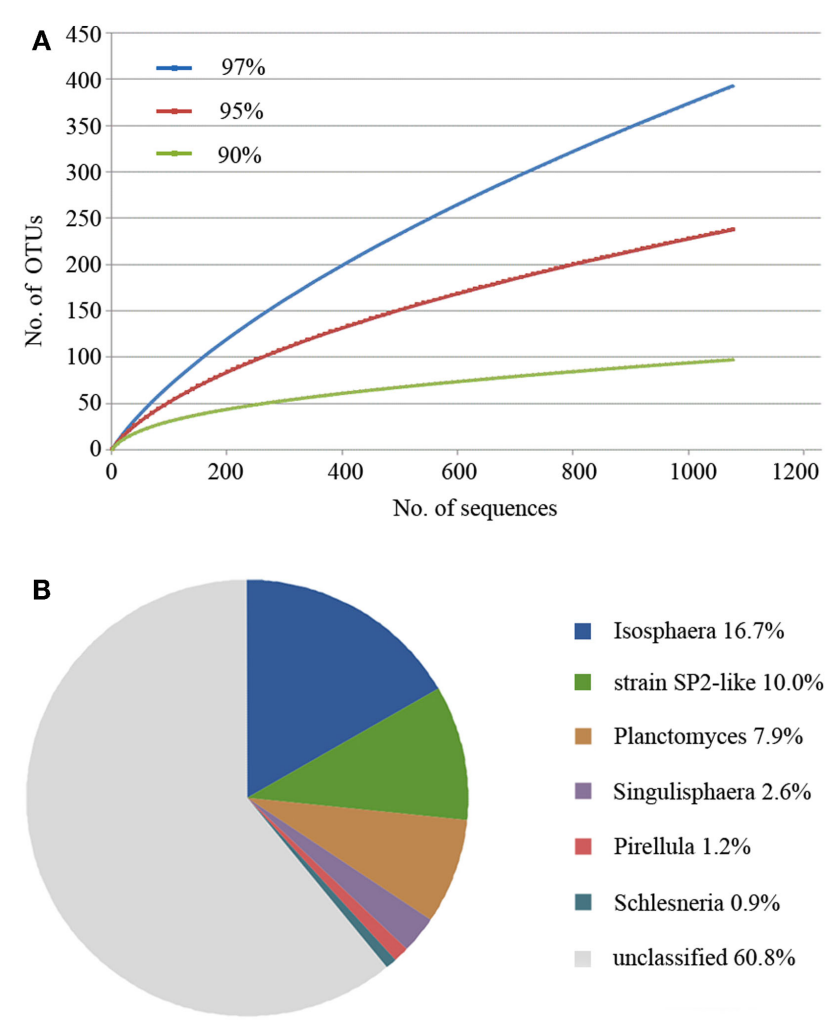

FIGURE 1 |The community composition of the Planctomycetes in an acidic peat sample as assessed by pyrosequencing-based analysis. The rarefaction curves show the relation between the retrieval of new planctomycete operational taxonomic units and the number of planctomycete sequences analyzed. Rarefaction analysis was performed at three sequence identity thresholds: 90,95 , and $97 \%$ (A). The pie chart shows the taxonomic distribution of the planctomycete sequences retrieved from a total data set of 21189 bacterial 454 sequences (B). obtained the second isolate, strain OB3, from another Sphagnum-dominated wetland, peat bog Obukhovskoye, using the same isolation approach. Sphagnum peat sample used for isolating strain $\mathrm{OB} 3$ was also used for the pyrosequencing-based Bacteria diversity analysis described above.

Strains $\mathrm{SP}^{\mathrm{T}}$ and $\mathrm{OB} 3$ shared identical $16 \mathrm{~S}$ rRNA gene sequences (Figure 2) and possessed a highly distinctive morphology. On media solidified with Phytagel, the two novel isolates formed small (1-2 mm), circular, pink-pigmented colonies with an entire edge and a smooth surface. These colonies were composed of non-motile, spherical cells, which varied in size from 1.2 to $2.0 \mu \mathrm{m}$ and reproduced by budding. In contrast to many other taxonomically characterized planctomycetes, buds of novel isolates were non-motile. On aging, cells formed rosettes or large, dendriform-like structures (Figure 3).

\section{GROWTH SUBSTRATES AND PHENOTYPIC CHARACTERISTICS}

At the stage of isolation, strains SP2 ${ }^{\mathrm{T}}$ and $\mathrm{OB} 3$ developed on a mineral medium solidified with Phytagel, an agar substitute produced from exopolysaccharide of Sphingomonas elodea. This polysaccharide is composed of glucuronic acid, rhamnose, and glucose. Presumably, Phytagel was used by strains $\mathrm{SP} 2^{\mathrm{T}}$ and $\mathrm{OB} 3$ as the carbon and energy source. Our attempts to maintain the isolates on agar medium M31 containing $0.1 \%(w / v) ~ N$-acetylglucosamine, which was used in our previous studies for cultivation of peatinhabiting planctomycetes (Kulichevskaya et al., 2007b, 2008, 2009, 2012), were unsuccessful. Long-term growth optimization procedures showed that strains SP2 ${ }^{\mathrm{T}}$ and OB3 do not develop on agar media. This is typical for many bacteria from northern wetlands (Dedysh, 2011).

Major phenotypic characteristics of strains $\mathrm{SP} 2^{\mathrm{T}}$ and $\mathrm{OB} 3$ are listed in Table 1. These bacteria were moderately acidophilic, mesophilic organisms capable of growth at $\mathrm{pH}$ values between 4.0 and 7.0 with an optimum at $\mathrm{pH} 5.0-5.5$ (Figure 4) and at temperatures between 6 and $30^{\circ} \mathrm{C}$ (with an optimum at $20-26^{\circ} \mathrm{C}$ ). Similar to phylogenetically related $Z$. formosa and G. obscuriglobus, the two novel isolates were obligately aerobic chemoheterotrophs. They were unable to grow in micro-oxic or anoxic conditions. $\mathrm{NaCl}$ inhibited growth at concentrations above $0.1 \%(\mathrm{w} / \mathrm{v})$.

The preferred growth substrates of strains SP2 ${ }^{\mathrm{T}}$ and $\mathrm{OB} 3$ were various heteropolysaccharides and sugars (Table 1), the latter

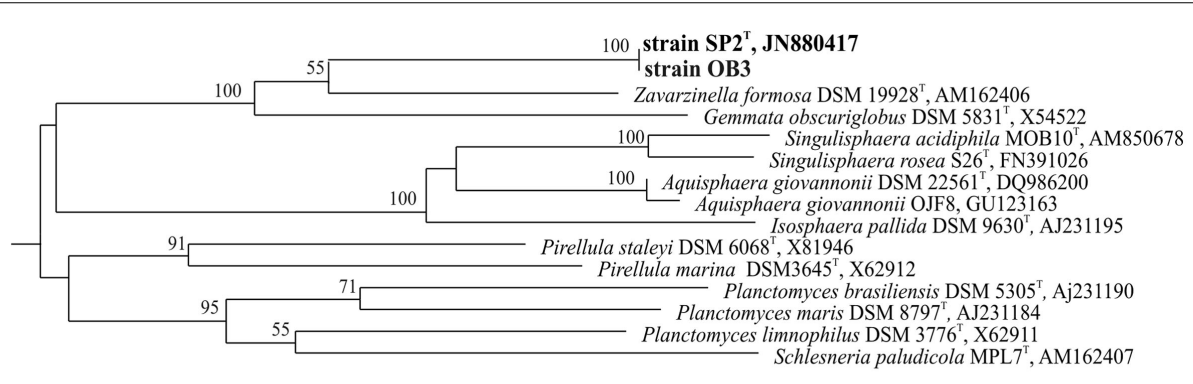

0.05

FIGURE 2 | 16S rRNA gene-based neighbor-joining tree showing the phylogenetic position of strains SP2 ${ }^{\top}$ and OB3 in relation to taxonomically characterized members of the phylum Planctomycetes. The root (not shown) was composed of five 16S rRNA gene sequences from anammox planctomycetes (AF375994, AF375995, AY254883, AY257181, AY254882). The scale bar represents 0.05 substitutions per nucleotide position. 


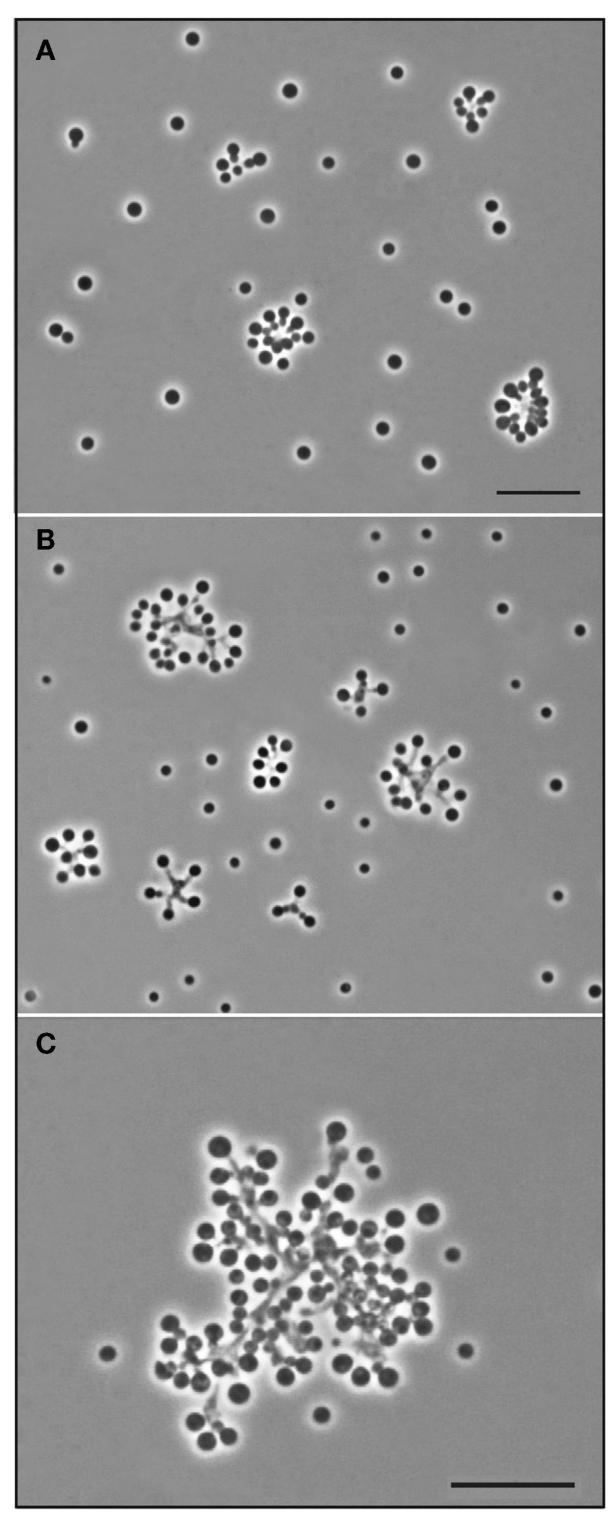

FIGURE 3 | Phase-contrast micrographs of cells and rosette-like cell clusters of strain SP2 grown for 10 days on solid medium M1N (A); cells of strain $\mathrm{SP2}^{\top}$ (B); and $\mathrm{OB} 3$ (C) arranged in dendriform-like structures after growth on solid medium M1N for 1 month; bar, $10 \mu \mathrm{m}$.

being utilized only if provided in low concentrations [below $0.025 \%(\mathrm{w} / \mathrm{v})]$. Growth inhibition of $60-70 \%$ was observed in the presence of substrates in the medium at a concentration of $0.05 \%$ $(\mathrm{w} / \mathrm{v})$, and substrate concentrations of $0.1 \%(\mathrm{w} / \mathrm{v})$ completely inhibited growth. A similar phenomenon was earlier reported for the filamentous planctomycete Isosphaera pallida (Giovannoni et al., 1987). Notably, $N$-acetylglucosamine was also utilized by strains SP2 ${ }^{\mathrm{T}}$ and OB3 only if provided in concentrations below $0.01 \%(\mathrm{w} / \mathrm{v})$. It appears that high concentrations of available substrates, which are provided in most of the routinely employed media, is one of the reasons for low planctomycete recovery in cultivation-based studies.

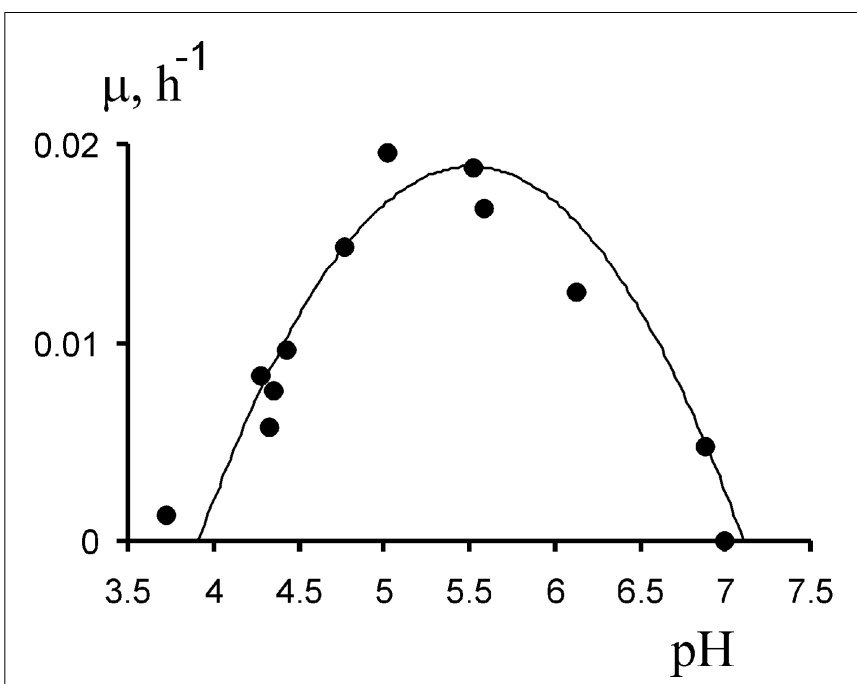

FIGURE 4 | Influence of medium pH on the growth of strain SP2 ${ }^{\top}$.

In contrast to other taxonomically characterized planctomycetes, strains $\mathrm{SP} 2^{\mathrm{T}}$ and $\mathrm{OB} 3$ displayed weak cellulolytic potential. Continuous $\mathrm{CO}_{2}$ production was detected during incubation of these bacteria with carboxymethyl cellulose, fibrous cellulose, and microcrystalline cellulose (Figure 5). Microscopic examination of the respective culture liquids revealed numerous cells of planctomycetes being attached to micro-particles of carboxymethyl cellulose (Figure 6, panel 1A,B) or micro-fibers of cellulose (Figure 6, panel 2A,B). The concentrations of reducing sugars detected in the medium after 30 days of cultivation comprised $0.071 \pm 0.012,0.063 \pm 0.007$, and $0.069 \pm 0.016 \mathrm{mg}$ per $\mathrm{ml}$ for carboxymethyl cellulose, fibrous and microcrystalline cellulose, respectively (compared to $0.010 \pm 0.005 \mathrm{mg}$ per $\mathrm{ml}$ at the beginning of the experiment and after 30 days of incubation in control). These values are one order of magnitude lower than those commonly measured for known fast-growing cellulose degraders. Other methods routinely employed for testing cellulose degrading capabilities in microorganisms, including cellulose disappearance from culture medium, could not be used for strains SP2 ${ }^{\mathrm{T}}$ and OB3 due to their very slow growth on this substrate. Obviously, cellulolytic potential of these planctomycetes cannot be compared to that in well-known cellulose degrading bacteria, such as clostridia, bacilli, or Cytophaga species. However, it is quite comparable to that in some slow-growing cellulolytic acidobacteria (Pankratov et al., 2011, 2012). It appears that strains $\mathrm{SP}^{\mathrm{T}}$ and OB3 can potentially play a role of slow-acting cellulose decomposers being, nonetheless, incapable of competing with traditionally known cellulose degraders. This hypothesis is supported by the fact that planctomycetes were identified as a numerically abundant component of a bacterial community that developed in the course of Sphagnum moss decomposition (Kulichevskaya et al., 2007a). The finding of weak cellulose degrading capabilities in strains $\mathrm{SP} 2^{\mathrm{T}}$ and $\mathrm{OB} 3$ strongly extends our understanding of the biogeochemical role of planctomycetes in peatlands and shows that they can function as slow-acting primary degraders in these ecosystems. 


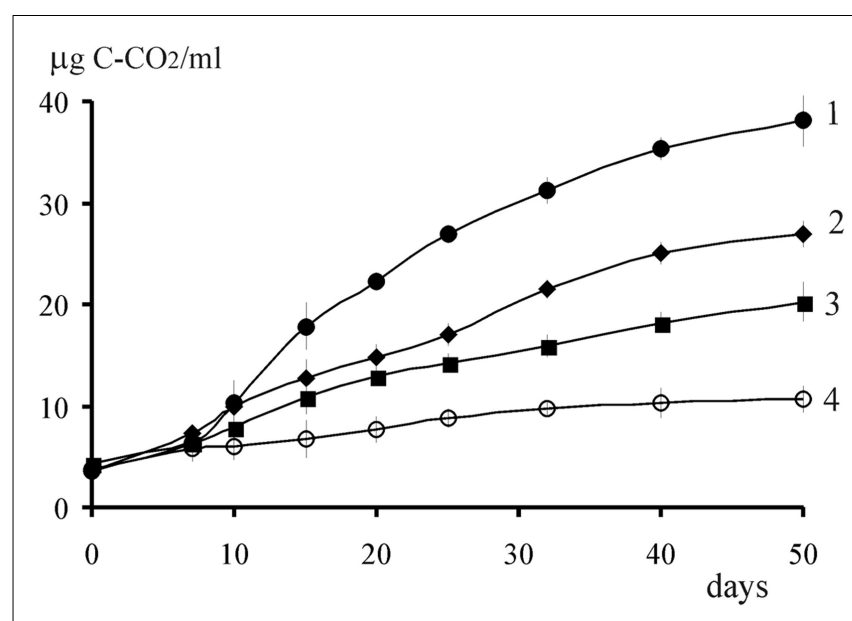

FIGURE 5 | Dynamics of $\mathrm{CO}_{2}$ production in experimental flasks with carboxymethyl cellulose (1), fibrous cellulose (2), and microcrystalline cellulose (3) versus control incubations (4). The increase in $\mathrm{CO}_{2}$ concentration in control flasks is due to the utilization of yeast extract used for medium preparation. Data are averages of three flasks \pm 1 STDEV. Where error bars are not visible, they are contained within the symbol.

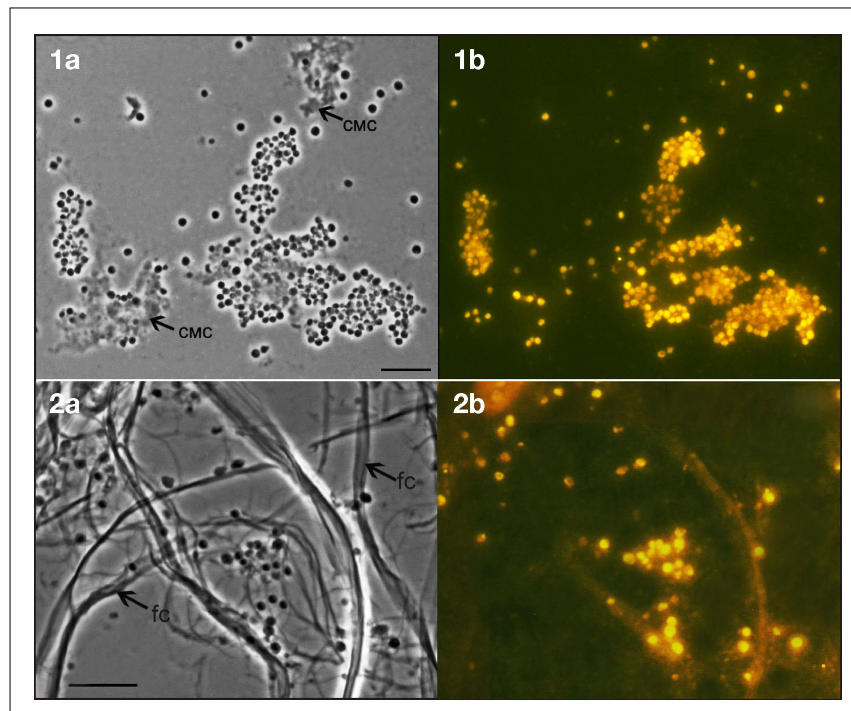

FIGURE 6 | Specific detection of cells of strain SP2 ${ }^{\top}$ grown on liquid medium M1 with carboxymethyl cellulose (CMC) (1) or fibrous cellulose (fc) (2) for 30 days by FISH: phase-contrast image (A); epifluorescent micrographs of in situ hybridizations with Cy3-labeled probes PLA46 and PLA886 (B); bar, $5 \mu \mathrm{m}$.

\section{LIPID COMPOSITION}

Both free and residually bound lipids of strains $\mathrm{SP} 2^{\mathrm{T}}$ and $\mathrm{OB} 3$ were analyzed and compared with those of $Z$. formosa $\mathrm{A} 10^{\mathrm{T}}$ and G. obscuriglobus DSM $5831^{\mathrm{T}}$. The major fatty acids of strain SP2 ${ }^{\mathrm{T}}$ and $\mathrm{OB} 3$ were $\mathrm{C} 16: 1 \omega 5 \mathrm{c}, \mathrm{C} 18: 0$, and $\mathrm{C} 18: 1 \omega 5 \mathrm{c}$ in both the extract and the residue after extraction (Table 2). This fatty acid profile is clearly distinct from that of G. obscuriglobus DSM $5831^{\mathrm{T}}$, which

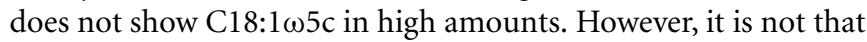
much different to the profile of $Z$. formosa $\mathrm{A} 10^{\mathrm{T}}$, although the latter contains substantially more of this fatty acid (Table 2). Saturated and monounsaturated C26-C32 ( $\omega-1)$ hydroxy fatty acids form a characteristic group of lipids of strains $\mathrm{SP}^{\mathrm{T}}$ and $\mathrm{OB} 3$ (Table 2). They occur only residually bound. The same series of $(\omega-1)$ hydroxy fatty acids was detected in $Z$. formosa $\mathrm{A} 10^{\mathrm{T}}$, but not in G. obscuriglobus DSM $5831^{\mathrm{T}}$ (Table 2).

The neutral lipids of strain $\mathrm{A} 10^{\mathrm{T}}$ are dominated by a polyunsaturated C31 hydrocarbon (Table 2) that has been detected in many other planctomycetes (Kulichevskaya et al., 2007b, 2008, 2009). Parkeol, a characteristic steroid of G. obscuriglobus DSM $5831^{\mathrm{T}}$ (Pearson et al., 2003), was not detected in strains SP2 ${ }^{\mathrm{T}}$ and OB3. Overall, the lipid profiles indicate that, based on chemotaxonomic criteria, strains $\mathrm{SP} 2^{\mathrm{T}}$ and $\mathrm{OB} 3$ are closer related to $Z$. formosa $\mathrm{A} 10^{\mathrm{T}}$ than to G. obscuriglobus DSM $5831^{\mathrm{T}}$.

In summary, strains $\mathrm{SP} 2^{\mathrm{T}}$ and $\mathrm{OB} 3$ were clearly distinct from $Z$. formosa $\mathrm{A} 10^{\mathrm{T}}$ and G. obscuriglobus DSM $5831^{\mathrm{T}}$. As compared to Gemmata and Zavarzinella, cells of the novel isolates were smaller in size and did not show motility; they displayed cellulolytic activity and utilized sugars and $N$-acetylglucosamine only when these substrates were provided in low concentrations $[<0.025 \%$ (w/v) for sugars and $<0.01 \%(\mathrm{w} / \mathrm{v})$ for $N$-acetylglucosamine]. In addition, the presence of a stalk, formation of rosettes or dendriform-like structures, and ability to grow in acidic conditions differentiated strains $\mathrm{SP} 2^{\mathrm{T}}$ and $\mathrm{OB} 3$ from G. obscuriglobus. Unique cell morphology, differences in substrate utilization patterns, and a number of chemotaxonomic and genotypic characteristics suggest that strains $\mathrm{SP} 2^{\mathrm{T}}$ and $\mathrm{OB} 3$ should be considered to represent a novel genus and species of planctomycetes, Telmatocola sphagniphila gen. nov., sp. nov. Strain SP2 ${ }^{\mathrm{T}}$ is the type strain (=DSM $23888^{\mathrm{T}}=$ VKM B- $2710^{\mathrm{T}}$ ).

\section{DESCRIPTION OF TELMATOCOLA gen. nov.}

Telmatocola (Tel.ma.to'co.la. Gr. n. telma - atos, swamp, bog; L. masc. or fem. suff. - cola (from L. n. incola) inhabitant, dweller; N.L.fem. n. Telmatocola a bog-dweller).

Spherical cells occur singly, in pairs or are assembled in large rosette-like clusters and dendriform-like structures during growth on solid media. Reproduce by budding. Both daughter and adult cells are non-motile. Produce stalk-like structures. Chemo-heterotrophic aerobe. Obligately oligotrophic. Moderately acidophilic and mesophilic. Major fatty acids are C18:0,

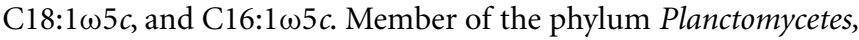
order Planctomycetales, family Planctomycetaceae. The type species is T. sphagniphila.

\section{DESCRIPTION OF TELMATOCOLA SPHAGNIPHILA sp. nov.}

Telmatocola sphagniphila (sphag.ni'phi.la. N.L. n. Sphagnum generic name of sphagnum moss; Gr. adj. philos loving; N.L. fem. adj. sphagniphila Sphagnum-loving).

Exhibit the following properties in addition to those given in the genus description. Colonies are pink. Mature spherical cells are non-motile $1.2-2.0 \mu \mathrm{m}$ in size. Catalase - positive and cytochrome - oxidase and urease - negative. Dissimilatory nitrate reduction and glucose fermentation are negative. Do not produce indole from tryptophane. Carbon sources $(0.025 \%$, w/v) include glucose, galactose, cellobiose, maltose, melizitose, mannose, rhamnose, ribose, sucrose, trehalose, xylose, salicin, and 
Table 2 | PLFA and neutral lipid composition of strains SP2 ${ }^{\top}$, OB3, Zavarzinella formosa A10 ${ }^{\top}$, and Gemmata obscuriglobus DSM $5831^{\top}$ (major PLFAs are shown in bold).

\begin{tabular}{|c|c|c|c|c|c|c|c|c|}
\hline \multirow[t]{2}{*}{$\%$ Of total } & \multicolumn{2}{|c|}{ Strain SP2 ${ }^{\top}$} & \multicolumn{2}{|c|}{ Strain OB3 } & \multicolumn{2}{|c|}{ Z. formosa } & \multicolumn{2}{|c|}{ G. obscuriglobus } \\
\hline & (1) & (2) & (1) & (2) & (1) & (2) & (1) & (2) \\
\hline $\mathrm{nC} 14: 0$ & & & & & 2.1 & 1.5 & & \\
\hline iC15:0 & & & & & 2.9 & 2.3 & & \\
\hline $\mathrm{nC} 16: 1 \omega 5 \mathrm{c}$ & 37.9 & 18.5 & 33.9 & 18.3 & 18.0 & 12.2 & 18.3 & 17.6 \\
\hline iC17:0 & 1.4 & 0.6 & 3.7 & 1.0 & 0.8 & & & \\
\hline aiC17:0 & & & 1.0 & & & & & \\
\hline $\mathrm{nC} 17: 0$ & 0.8 & 1.4 & 2.2 & 2.8 & & & & \\
\hline $\mathrm{nC} 18: 1 \omega 9 \mathrm{c}$ & 1.3 & 0.8 & 0.7 & 0.7 & & & 0.7 & 0.7 \\
\hline $\mathrm{nC} 18: 1 \omega 5 \mathrm{c}$ & 36.8 & 15.0 & 24.8 & 9.4 & 48.7 & 21.2 & 1.7 & 1.3 \\
\hline $\mathrm{nC} 18: 0$ & 9.6 & 25.7 & 16.4 & 33.2 & 11.6 & 15.8 & 61.1 & 59.1 \\
\hline$(\omega-1) \mathrm{OH}-\mathrm{C} 28: 1$ & & 0.6 & & 0.9 & & 9.0 & & \\
\hline$(\omega-1) \mathrm{OH}-\mathrm{C} 28: 0$ & & & & 1.6 & & 8.4 & & \\
\hline$(\omega-1) \mathrm{OH}-\mathrm{C} 30: 1$ & & 28.7 & & 25.2 & & 18.7 & & \\
\hline$(\omega-1) \mathrm{OH}-\mathrm{C} 30: 0$ & & & & & & 3.0 & & \\
\hline$(\omega-1) \mathrm{OH}-\mathrm{C} 32: 1$ & & 4.8 & & 3.2 & & 1.5 & & \\
\hline \multicolumn{9}{|c|}{ NEUTRAL LIPIDS } \\
\hline$n-C 31: 9$ & 4.2 & & 5.0 & & 7.9 & & 8.9 & \\
\hline Parkeol & & & & & & & 2.8 & \\
\hline
\end{tabular}

(1) Base hydrolyzed extract.

(2) Base hydrolyzed residue after extraction.

$N$-acetylglucosamine $(<0.01 \%)$. Hydrolyze laminarin, aesculin, starch, gelatin, lichenan, gellan-gum, phytagel, xanthan, and xylan. Possess weak cellulolytic potential and capable of slow growth on carboxymethyl cellulose, fibrous, and microcrystalline cellulose. Cannot utilize lactose, fructose, sorbose, fucose, glycerol, gluconate, methanol, ethanol, galacturonate, acetate, benzoate, caproate, citrate, formate, formaldehyde, fumarate, glutarate, lactate, malate, succinate, propionate, mannitol, tartrate, alanine, arginine, asparagine, aspartate, cysteine, cystine, glutamine, glycine, histidine, isoleucine, leucine, lysine, methionine, norleucine, ornithine, phenylalanine, proline, serine, threonine, tryptophan, tyrosine, valine. Cannot hydrolyze casein, chondroitin sulfate, pectin, chitosan, and chitin. Shows the following enzyme activities: alkaline and acid phosphatase, esterase, esterase lipase, leucine arylamidase, cystine arylamidase, valine arylamidase, phosphohydrolase, $N$-acetyl- $\beta$-glucosaminidase, $\beta$ galactosidase (API ZYM test). Utilize nitrate, ammonia, Bacto

\section{REFERENCES}

Bondoso, J., Albuquerque, L., Nobre, F., Lobo-da-Cunha, A., da Costa, M. S., and Lage, O. M. (2011). Aquisphaera giovannonii gen. nov., sp. nov., a novel planctomycete isolated from a freshwater aquarium. Int. J. Syst. Evol. Microbiol. 61, 2844-2850.
Dedysh, S. N. (2011). Cultivating uncultured bacteria from Northern wetlands: knowledge gained and remaining gaps. Front. Microbiol. 2:184. doi:10.3389/fmicb.2011. 00184

Dedysh, S. N., Pankratov, T. A., Belova, S. E., Kulichevskaya, I. S., and

Yeast Extract, glutamine, asparagine as nitrogen sources. Sensitive to novobiocin, kanamycin, and gentamicin, but resistant to ampicillin, chloramphenicol, streptomycin, cycloserine, and neomycin. Growth occurs at $\mathrm{pH} 4.0-7.0$ (optimum, $\mathrm{pH}$ 5.0-5.5) and at temperatures between 6 and $30^{\circ} \mathrm{C}$ (optimum, 20-26 $6^{\circ} \mathrm{C}$ ). $\mathrm{NaCl}$ inhibits growth at concentrations above $0.1 \%(\mathrm{w} / \mathrm{v})$. The $\mathrm{G}+\mathrm{C}$ content of the DNA varies between 58.5 and $59.0 \mathrm{~mol} \%$ ( $58.5 \mathrm{~mol} \%$ for the type strain). Sphagnum peat bogs are the main habitat. The type strain is strain SP2 ${ }^{\mathrm{T}}\left(=\mathrm{DSM} 23888^{\mathrm{T}}=\mathrm{VKM} \mathrm{B}-2710^{\mathrm{T}}\right)$, which was isolated from the Sphagnum peat bog Staroselsky moss, Tver region, European North Russia.

\section{ACKNOWLEDGMENTS}

This research was supported by the Program "Molecular and Cell Biology" of Russian Academy of Sciences, the Russian Fund of Basic Research (project No 12-04-00480), and the Deutsche Forschungsgemeinschaft (LI 455/5-1).

Liesack, W. (2006). Phylogenetic analysis and in situ identification of Bacteria community composition in an acidic Sphagnum peat bog. Appl. Environ. Microbiol. 72, 2110-2117.

Edgar, R. C., Haas, B. J., Clemente, J. C., Quince, C., and Knight, R.
(2011). UCHIME improves sensitivity and speed of chimera detection. Bioinformatics. 27, 2194-2200.

Franzmann, P. D., and Skerman, V. B. D. (1984). Gemmata obscuriglobus, a new genus and species of the budding bacteria. Antonie Van Leeuwenhoek 50, 261-268. 
Fuerst, J. A. (1995). The planctomycetes: emerging models for microbial ecology, evolution and cell biology. Microbiology 141, 1493-1506.

Fuerst, J. A. (2005). Intracellular compartmentation in planctomycetes. Annu. Rev. Microbiol. 59, 299-328.

Fuerst, J. A., and Sagulenko, E. (2011). Beyond the bacterium: planctomycetes challenge our concepts of microbial structure and function. Nat. Rev. Microbiol. 9, 403-413.

Gerhardt, P. (1981). Manual of Methods for General Bacteriology. Washington, DC: American Society for Microbiology.

Gimesi, N. (1924). Hydrobiologiai Tanumalmanyok. I. Planctomyces bekefii Gim. nov. gen. et sp. Budapest: Kiadja a Magyar Ciszterci Rend, 1-8.

Giovannoni, S. J., Schabtach, E., and Castenholz, R. W. (1987). Isosphaera pallida, gen. nov., and comb. nov., a gliding, budding eubacterium from hot springs. Arch. Microbiol. 147, 276-284.

Goossens, H., de Leeuw, J. W., Rijpstra, W. I. C., Meyburg, G. J., and Schenck, P. A. (1989). Lipids and their mode of occurrence in bacteria and sediments. I. A methodological study of the lipid composition of Acinetobacter calcoaceticus LMD 79-41. Org. Geochem. 14, 15-25.

Hirsch, P., and Müller, M. (1985). Planctomyces limnophilus sp. nov., a stalked and budding bacterium from fresh water. Syst. Appl. Microbiol. 6, 276-280.

Ivanova, A. O., and Dedysh, S. N. (2012). Abundance, diversity and depth distribution of planctomycetes in acidic northern wetlands. Front. Microbiol. 3:5. doi:10.3389/fcimb.2012.00005

Kulichevskaya, I. S., Baulina, O. I., Bodelier, P. L. E., Rijpstra, W. I. C., Sinninghe Damsté, J. S., and Dedysh, S. N. (2009). Zavarzinella formosa gen. nov., sp. nov., a novel stalked, Gemmata-like planctomycete from a Siberian peat bog. Int. J. Syst. Evol. Microbiol. 59, 357-364.

Kulichevskaya, I. S., Belova, S. N., Kevbrin, V. V., Dedysh, S. N., and Zavarzin, G. A. (2007a). Analysis of the bacterial community developing in the course of Sphagnum moss decomposition. Microbiology 76, 621-629.

Kulichevskaya, I. S., Ivanova, A. O., Belova, S. E., Baulina, O. I., Bodelier, P. L. E., Rijpstra, W. I. C., Sinninghe Damsté, J. S., Zavarzin, G. A., and Dedysh, S. N. (2007b). Schlesneria paludicola gen. nov., sp. nov., the first acidophilic member of the order Planctomycetales from
Sphagnum-dominated boreal wetlands. Int. J. Syst. Evol. Microbiol. 57, 2680-2687.

Kulichevskaya, I. S., Detkova, E. N., Bodelier, P. L. E., Rijpstra, W. I. C., Sinninghe Damsté, G. S., and Dedysh, S. N. (2012). Singulisphaera rosea sp. nov., a novel planctomycete from acidic Sphagnum peat. Int. J. Syst. Evol. Microbiol. 62, 118-123.

Kulichevskaya, I. S., Ivanova, A. O., Baulina, O. I., Bodelier, P. L. E., Sinninghe Damsté, J. S., and Dedysh, S. N. (2008). Singulisphaera acidiphila gen. nov., sp. nov., a nonfilamentous, Isosphaera-like planctomycete from acidic northern wetlands. Int. J. Syst. Evol. Microbiol. 58, 1186-1193.

Kulichevskaya, I. S., Pankratov, T. A., and Dedysh, S. N. (2006). Detection of representatives of the planctomycetes in Sphagnum peat bogs by molecular and cultivation approaches. Microbiology 75, 329-335.

Lane, D. J. (1991). “16S/23S rRNA sequencing," in Nucleic Acid Techniques in Bacterial Systematics, eds E. Stackenbrandt and M. Goodfellow (Chichester: John Wiley and Sons Ltd.), 115-175.

Ludwig, W., Strunk, O., Westram, R., Richter, L., Meier, H., Kumar, Y., Buchner, A., Lai, T., Steppi, S., Jobb, G., Förster, W., Brettske, I., Gerber, S., Ginhart, A. W., Gross, O., Grumann, S., Hermann, S., Jost, R., König, A., Liss, T., Lüßmann, R., May, M., Nonhoff, B., Reichel, B., Strehlow, R., Stamatakis, A., Stuckman, N., Vilbig, A., Lenke, M., Ludwig, T., Bode, A., and Schleifer, K.-H. (2004). ARB: a software environment for sequence data. Nucleic Acids Res. 32, 1363-1371.

Marmur, J. (1961). A procedure for the isolation of DNA from microorganisms. J. Mol. Biol. 3, 208-218.

Miller, G. L. (1959). Use of dinitrosalicylic acid reagent for determination of reducing sugar. Anal. Chem. 31, 426-428.

Neef, A., Amann, R., Schlesner, H., and Schleifer, K.-H. (1998). Monitoring a widespread bacterial group: in situ detection of planctomycetes with 16S rRNA-targeted probes. Microbiology 144, 3257-3266.

Owen, R. J., Lapage, S. P., and Hill, L. R. (1969). Determination of base composition from melting profiles in dilute buffers. Biopolymers 7, 503-516.

Pankratov, T. A., Ivanova, A. O., Dedysh, S. N., and Liesack, W. (2011). Bacterial populations and environmental factors controlling cellulose degradation in an acidic Sphagnum peat. Environ. Microbiol. 11, 1800-1814.

Pankratov, T. A., Kirsanova, L. A., Kaparullina, E. N., Kevbrin, V.V., and Dedysh, S. N. (2012). Telmatobacter bradus gen. nov., sp. nov., a cellulolytic facultative anaerobe from subdivision 1 of the Acidobacteria and emended description of Acidobacterium capsulatum Kishimoto et al. 1991. Int. J. Syst. Evol. Microbiol. 62, 430-437.

Pearson, A., Budin, M., and Brocks, J. J. (2003). Phylogenetic and biochemical evidence for sterol synthesis in the bacterium Gemmata obscuriglobus. Proc. Natl. Acad. Sci. U.S.A. 100, 15352-15357.

Pruesse, E., Quast, C., Knittel, K., Fuchs, B., Ludwig, W., Peplies, J., and Glöckner, F. O. (2007). SILVA: a comprehensive online resource for quality checked and aligned ribosomal RNA sequence data compatible with ARB. Nucleic Acids Res. 35, 7188-7196.

Schlesner, H. (1994). The development of media suitable for the microorganisms morphologically resembling Planctomyces spp., Pirellula spp., and other Planctomycetales from various aquatic habitats using dilute media. Syst. Appl. Microbiol. 17, 135-145.

Schlesner, H., and Hirsch, P. (1987). Rejection of the genus name Pirella for pear-shaped budding bacteria and proposal to create the genus Pirellula gen. nov. Int. J. Syst. Bacteriol. 37, 441 .

Schlesner, H., Rensmann, C., Tindall, B. J., Gade, D., Rabus, R., Pfeiffer, S., and Hirsch, P. (2004). Taxonomic heterogeneity within the Planctomycetales as derived by DNADNA hybridization, description of Rhodopirellula baltica gen. nov., sp. nov., transfer of Pirellula marina to the genus Blastopirellula gen. nov. as Blastopirellula marina comb. nov. and emended description of the genus Pirellula. Int. J. Syst. Evol. Microbiol. 54, 1567-1580.

Schloss, P. D., Westcott, S. L., Ryabin, T. Hall, J. R., Hartmann, M., Hollister, E. B., Lesniewski, R. A., Oakley, B. B. Parks, D. H., Robinson, C. J., Sahl, J. W., Stres, B., Thallinger, G. G., Van Horn, D. J., and Weber, C. F. (2009). Introducing Mothur: open-source, platform-independent, communitysupported software for describing and comparing microbial communities. Appl. Environ. Microbiol. 75, 7537-7541.
Staley, J. T., Fuerst, J. A., Giovannoni, S., and Schlesner, H. (1992). "The order Planctomycetales and the genera Planctomyces, Pirellula, Gemmata and Isosphaera," in The Prokaryotes: A Handbook on the Biology of Bacteria: Ecophysiology, Isolation, Identification, Applications, 2nd Edn, eds A. Balows, H. Truper, M. Dworkin, W. Harder, and K.H. Schleifer (New York: SpringerVerlag), 3710-3731.

Starr, M. R., and Schmidt, J. M. (1984). Planctomyces stranskae (ex Wawrik 1952) sp. nov., nom. rev. and Planctomyces guttaeformis (ex Hortobagyi 1965) sp. nov., nom. rev. Int. J. Syst. Bacteriol. 34, 470-477.

Ward, N., Staley, J. T., Fuerst, J. A., Giovannoni, S., Schlesner, H., and Stackebrandt, E. (2006). "The order Planctomycetales, including the genera Planctomyces, Pirellula, Gemmata and Isosphaera and the Candidatus genera Brocadia, Kuenenia and Scalindua," in The Prokaryotes: A Handbook on the Biology of Bacteria, 3rd Edn, Vol. 7, eds M. Dworkin, S. Falkow, E. Rosenberg, K. H. Schleifer, and E. Stackebrandt (New York: Springer), 757-793.

Weisburg, W. G., Barns, S. M., Pelletier, D. A., and Lane, D. J. (1991). 16S ribosomal DNA amplification for phylogenetic study. J. Bacteriol. 173, 697-703.

Conflict of Interest Statement: The authors declare that the research was conducted in the absence of any commercial or financial relationships that could be construed as a potential conflict of interest.

Received: 20 January 2012; accepted: 27 March 2012; published online: 17 April 2012.

Citation: Kulichevskaya IS, Serkebaeva $Y M$, Kim Y, Rijpstra WIC, Damsté JSS, Liesack W and Dedysh SN (2012) Telmatocola sphagniphila gen. nov., sp. nov., a novel dendriform planctomycete from northern wetlands. Front. Microbio. 3:146. doi: 10.3389/fmicb.2012.00146

This article was submitted to Frontiers in Evolutionary and Genomic Microbiology, a specialty of Frontiers in Microbiology. Copyright (C) 2012 Kulichevskaya, Serkebaeva, Kim, Rijpstra, Damsté, Liesack and Dedysh. This is an open-access article distributed under the terms of the Creative Commons Attribution Non Commercial License, which permits noncommercial use, distribution, and reproduction in other forums, provided the original authors and source are credited. 